\title{
INTERNAL AND EXTERNAL DETERMINANTS OF HOUSING PRICE BOOM IN HONG KONG
}

\author{
Farhad Taghizadeh-Hesary*, Naoyuki Yoshino**, Aline Mortha***, \\ Alvin Chiu ${ }^{* * *}, \&$ Niki Naderi***** \\ ${ }^{*}$ Corresponding author, Social Science Research Institute, Tokai University, Hiratsuka, Kanagawa, Japan, \\ Email: farhad@tsc.u-tokai.ac.jp; farhadth@gmail.com \\ ${ }^{* *}$ Keio University, Tokyo, Japan \\ ***Graduate School of Economics, Waseda University, Tokyo, Japan \\ ****School of Interdisciplinary Area Studies, University of Oxford, United Kingdom \\ *****Azad University Tehran North, Tehran, Iran
}

\begin{abstract}
Hong Kong's housing market witnessed a dramatic housing price appreciation in recent years, with the price index for private domestic housing units being three times higher than ten years ago. This trend is supported by both internal and external factors, as illustrated in this paper. By developing a theoretical model and an empirical analysis on the key variables influencing housing prices using monthly data from 1999 to 2018, we find that the main drivers of housing price appreciation are from the demand side and include income level, money supply and inflation. The main contribution of this study is the quantification of the role of Mainland China's macroeconomic factors in housing price booms in Hong Kong. Our study shows that capital inflow from and inflation and recessions in Mainland China contribute to increasing housing prices in Hong Kong because the city's real estate is seen as a way to preserve asset value. These findings call for the need for control of capital inflow between the two economies as well as for stricter regulations against empty houses in Hong Kong.
\end{abstract}

Keywords: Housing bubbles; Housing prices; Housing market; Monetary policy. JEL Classifications: R31; E51; E31.

Article history:

Received : March 22, 2019

Revised : June 27, 2020

Accepted : November 27, 2020

Available Online: January 31, 20210

https://doi.org/10.21098/bemp.v23i4.1043 


\section{INTRODUCTION}

One of the most expensive cities in the world, according to the Economist's Worldwide Cost of Living Survey, Hong Kong has witnessed a dramatic appreciation of its real estate prices in the past decades, as shown in Figure 1, which displays the housing price index in Hong Kong.

Figure 1.

\section{Housing Price Index in Hong Kong (April 1997-September 2018)}

The figure shows the housing price index in Hong Kong, over the period of April 1997 to September 2018. The data is retrieved from the Government of Hong Kong, (2019).

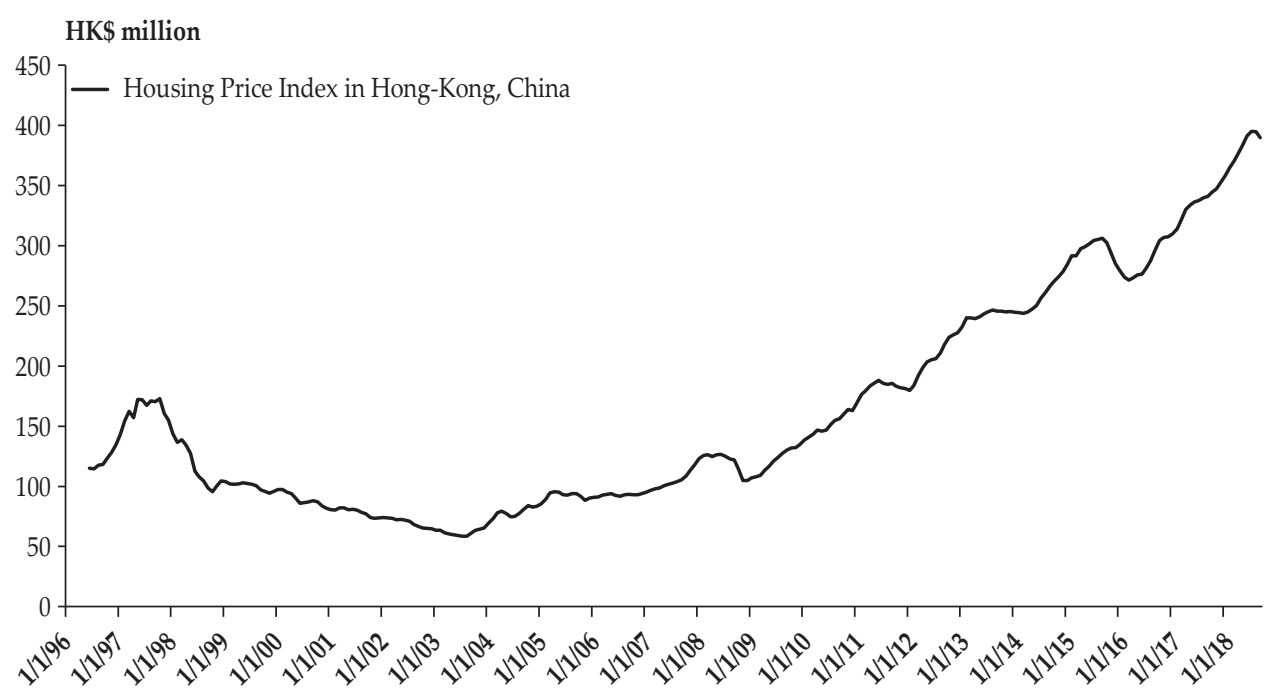

The housing price index in the city has been increasing since 2003. The index witnessed a spike in 1997, following the Asian Financial Crisis, and steadily went up after the Severe Acute Respiratory Syndrome (SARS) epidemic (2003), after which the government voluntarily reduced real estate supply by halting new construction of the home-ownership scheme and adopting a passive land auction policy (Wong, 2008).

Interestingly enough, this period also coincides with the rise in Chinese foreign direct investment. The position of China's flow of direct investment in Hong Kong rose from only 35.26 billion $\mathrm{HKD}^{1}$ (APEC, 2020) to over 296.6 billion HKD at the end of 2018 (Census and Statistics Department, 2020). Expansion of Chinese corporations abroad worked in hand with the monetary policy implemented by the People's Bank of China. The similarity in movements between the housing price index and Chinese foreign direct investment can be explained by the fact that foreign direct investment (FDI) and foreign trade of Hong Kong is predominantly related to the People's Republic of China (hereafter, PRC).

1 The USD 4.533 billion value converted to HKD using the average exchange rate of USD/HKD which was 7.78 in 2003. 
Booming real estate prices pose several issues. Increased inequalities may arise because of the "wealth effect", as homeowners' income grows while those who do not own property suffer in consequence. ${ }^{2}$ Increased inequalities are concerning, as they are associated with social unrest and higher poverty and can hinder economic growth in the long run. Besides, the real estate bubble experience in Japan between the 1980s and 1990s shows that excess credit devoted to the real estate market is detrimental in the long run (Yoshino and Taghizadeh-Hesary, 2016). Japan's experience of a prolonged recession in the aftermath of the bubble's burst is another negative consequence of the presence of bubbles in real estate. The trend in housing prices in Hong Kong resulted in many studies investigating a housing bubble in the economy (Ahuja \& Porter, 2010; Kalra, Mihaljek and Duenwald, 2000; Yiu, Yu and Jin, 2013). While the study of Kalra et al. (2000) confirmed the presence of speculative bubbles between 1980 and 1998, more recent studies reject this hypothesis (Ahuja \& Porter, 2010), although these studies highlight that the tendency for wealthy Chinese mainlanders to buy property in Hong Kong may lead to speculative bubbles in the near future. Using a new methodology for bubble detection, Yiu et al. (2013) confirmed the presence of short-lived bubbles in 1995, 1997, 2004, and 2008, but rejected the presence of a longer-lasting one.

Given the trend of housing prices in Hong Kong, and the potential damages it could cause to the economy, it is crucial to determine what factors drive this appreciation.

Many articles have been devoted to analyzing the determinants of housing prices in Hong Kong (Craig \& Hua, 2011; Glindro, Subhanji, Szeto and Zhu, 2008; Kalra, et al., 2000; Leung, Cjow and Han, 2008; Wu, Wong and Chen, 2017). However, the vast majority of them only focused on analyzing factors linked to demand and supply inside Hong Kong. This paper contributes to the existing literature by adding external factors and economic indicators from the PRC as well as internal factors in its analysis of the housing price determinants in Hong Kong. The paper is organized as follows. Section II is dedicated to reviewing the literature on the determinants of housing prices, on the demand and supply side as well as on the policy side and external factors. This section also reviews previous papers investigating the case of Hong Kong. Section III is dedicated to providing a theoretical model for the paper. Then, Section IV presents our empirical analysis. Section $\mathrm{V}$ provides a conclusion and policy recommendations.

\section{DETERMINANTS OF HOUSING PRICES}

Since this study aims at analyzing the determinants of housing prices, this section is dedicated to reviewing the literature on the topic. To be precise, the determinants are classified by theme, and each sub-section will explore one theme. Reviewing the literature on the determinants of housing prices is also crucial in determining the variables that will be used in our empirical analysis.

\footnotetext{
2 Inequalities worsen as housing prices increase, through an alternative channel called the collateral effect channel. The increase in housing prices further enhances home asset values, thus, enhancing the collateral position of homeowners, who in turn buy more houses at the expense of the poor (see Iyke, 2018).
} 


\section{A. Determinants from Demand and Supply}

Several studies analyzing the determinants of housing prices in Hong Kong and the rest of the world emphasize the importance of demand and supply factors.

To analyze the sources of changes in housing prices, several articles consider demand-side factors. Studies by Kalra et al. (2000), Glindro et al. (2008), and Bian and Gete (2015) have included a demographic variable in their analysis of Hong Kong, Asia-Pacific, and Chinese housing markets. Even though in the case of Hong Kong, the variable did not return statistically significant results, this variable is crucial in analyzing the drivers of housing demand and is especially important for cities with limited land supply. Another variable that is often considered as a driving force of housing prices is the level of income (as measured by the level of gross domestic product (GDP) per capita) and economic activity (GDP). Real GDP is used in Glindro et al. (2008), although per capita income is the most widely used control variable (see Craig \& Hua, 2011; Kalra et al., 2000; Leung et al., 2008; Tsai \& Peng, 2011; Wu, Wong \& Chen, 2017, among other studies). It is logical to see an appreciation of housing prices, as the economy develops and per capita income increases. A higher income per capita and capital deepening, translates into increased demand and increased prices of all commodities, including housing (Chen, Long, Qing, 2020). Hence, real GDP or GDP per capita is a decisive control variable. When taking into account the demand side, it is also important to include factors that reflect preference towards housing, in some capacity, as Bian \& Gete (2015) do.

In the case of Hong Kong, including factors that affect the supply side of the housing market is also critical. Since the city is essentially built on an island, increasing the land supply is not as straightforward as it would be for other cities. For this reason, some studies focusing on Hong Kong incorporated a land supply index and construction costs to measure this particular effect (Craig \& Hua, 2011; Glindro et al., 2008; Leung et al., 2008). Bank lending conditions are another supply-side factor and are important to take into account when examining the determinants of housing prices. If tightened, bank lending conditions can severely reduce housing supply, creating a vicious circle of a cut in supply that will drive prices up, rendering housing even less affordable. To this end, studies generally look into the mortgage rate and the lending rate (Glindro et al., 2008; Hui \& Wang, 2014; Tsai \& Peng, 2011; Wu, et al., 2017) or into the number of mortgage loans approved within a given period (Wu, et al., 2017) and domestic credit (Craig \& Hua, 2011; Justiniano, Primiceri \& Tambalotti, 2015). In particular, Justiniano et al. (2015) showed that looser lending constraints in the mortgage market were the major driver behind housing price appreciation in the US. Interestingly, they invalidated the popular assertion that a lower collateral requirement was the driver for housing price appreciation. Instead, they suggested that, at the peak of the housing market, the lowering of the collateral requirements caused a fall in housing prices.

\section{B. Policy Determinants}

While demand and supply variables are important factors that determine housing prices, they are also factors upon which policymakers cannot act to slow down 
housing appreciation. On the other hand, a review of the literature proved that there are many types of policies that have an impact on housing prices, including monetary policies, fiscal policies, as well as institutional factors.

Monetary policies, including policies related to money supply, the interest rate and inflation rate, are proven to be decisive factors in determining housing prices. Su, Wang, Tao, and Chang (2019), who examined the causality between housing prices and money supply in PRC from January 1998 to December 2016, has found the existence of a time-varying, "bidirectional causal link" between housing prices and money supply in PRC. Tsai \& Peng (2011) showed a strong correlation between money supply and bubble indicators in Taiwan. Besides, Su et al. (2019) showed that the bubble and bust cycle of housing prices can both positively and negatively affect money supply in the PRC in different sub-periods. Meanwhile, the money supply has a positive impact on housing prices as well. The transmission mechanism of money supply to the economy and housing markets is more complex than simply through changing the cost of capital.

Another key factor that affects housing prices is the inflation rate. A higher inflation rate translates into higher commodity prices, including housing prices. Tsai \& Peng (2011) demonstrated the importance of inflation rate in the detection of housing bubbles. Taghizadeh-Hesary \& Yoshino (2016) proved that the monetary policy of the US impacts global commodities' prices, including crude oil prices, which are the key components of inflation. This link is especially prominent in emerging markets like the PRC, in comparison with developed countries. Several other studies have found a positive association between monetary policy and asset and commodities markets (Taghizadeh-Hesary \& Yoshino 2014; Yoshino \& Taghizadeh-Hesary 2014).

Interest rate policies are also shown to have a certain impact on housing prices, as they directly influence bank lending conditions in the economy. Studies focusing on policy evaluation such as Craig \& Hua (2011) and Leung et al. (2008) integrate this variable in their study, even though their study showed that interest rate was not statistically significant or played a small role in comparison with other macroeconomic variables. Nevertheless, this particular variable is a longterm determinant of housing prices (Ho \& Wong, 2008; Leung et al., 2008).

A few studies also discussed the role of fiscal policies and tax adjustments on housing prices (Hui \& Wang, 2014), as tax adjustments may tighten or loosen constraints on land supply. Finally, Glindro et al. (2008) used an institutional indicator in their analysis of the determinants of housing prices in Asia-Pacific economies. Their institutional factor is based on the principal component of four institutional indices, namely the business freedom index, the financial freedom index, the corruption index and the property rights index (Glindro et al., 2008: p. 349 ), and proved to be statistically significant in their panel regressions. However, Glindro et al. (2008) also found, in their country-specific model, that the institutional factor is not significant in the case of Hong Kong.

\section{External Determinants}

Since this explores the external determinants of property prices as well, it is important to review the literature on external factors affecting housing prices. 
Capital inflow has long been elaborated as being positively related to housing prices. Many economists concur that capital inflow significantly contributes to the upsurge in property prices. For example, Yiu and Sahminan (2015) documented that the excess global liquidity and capital inflows that followed the quantitative easing policy adopted by the advanced economies since 2009 led to the upsurge in housing prices in the Association of Southeast Asian Nations (ASEAN) economies. Specifically, they attributed the rapid surge in housing prices in the ASEAN-5 economies (Indonesia, Malaysia, the Philippines, Singapore and Thailand) to strong capital inflows experienced by these countries. Yiu and Sahminan (2015) noted that, even after accounting for their domestic demand (by using real GDP growth as a proxy), capital inflows still have a positive impact on housing prices in Indonesia and Singapore. Besides, studies by Hui and Wang (2014) and Leung et al. (2008) highlighted the importance of investment (whether external or internal) in determining property prices in PRC and Hong Kong.

Another study that drew the same conclusion is Sa and Wieladek (2011), which compared the magnitude of the effect of monetary policy and capital inflow shocks on the US housing market. Using the open economy vector autoregressive (VAR) model, Sa and Wieladek (2011) found that monetary policy shocks have produced a limited effect on housing prices. In contrast, capital inflows have a more positive and long-lasting effect on housing prices. Similarly, Guest and Rohde (2017) found that direct foreign investment in the housing market has caused housing price appreciation in the long run and their argument is echoed by Wokker and Swieringa (2016).

Although usually less used in studies, other minor external factors can influence housing prices. For instance, Ho and Wong (2008) showed that exports are statistically significant and are responsible for long-term developments in the housing market. Utilizing an autoregressive distributed lag (ARDL) model, they found that exports led to domestic consumption and hence investments. Finally, Glindro et al. (2008) used several variables to reflect the relative price of other commodities, namely equity prices and exchange rates, as housing prices share a tendency to commove with other assets, and exchange rate appreciation can have lead to housing appreciation. They found both equity prices and exchange rate to be statistically significant in explaining housing prices in the long run in Hong Kong.

As the aforementioned studies have not provided an overarching view that compares and contrasts the factors behind housing price appreciation, but focused on domestic causes, our study considers a wide range of internal and external factors driving this phenomenon (i.e. housing price appreciation), as illustrated in the following sections.

\section{THEORETICAL MODEL}

This section shows mathematically which factors influence housing price boom. Based on the theoretical model that we developed in this section, we then develop our empirical model in Section IV.

The housing demand is shown with downward sloping curves in Figure

2. Housing demand $\left(H_{t}^{d}\right)$ is showed in Equation (1) and it depends on constant 
demand for houses $\left(d_{0}\right)$, housing prices $\left(P_{t}^{H}\right)$, the interest rate on housing loan $\left(r_{t}\right)$, expected housing prices $\left(P_{t}^{H^{e}}\right)$, households' income level $\left(Y_{t}\right)$ and inflow of foreign capital $\left(F D I_{t}\right)$.

When the economy is booming, the income level increases, so the housing price goes up. In the short-run, housing construction is very slow, so, housing supply is fixed at $\bar{H}^{s}$ as shown in Figure 2 and Equation (2).

When the economy is in a downturn, interest rates will be lowered by the monetary authority. Then, housing demand starts to rise because interest rates on housing loans have fallen. Accordingly, housing prices start to rise, as shown in Figure 2. Then, people expect that housing price to further increase $\left(P_{t}^{H^{e}}\right)$, as a result, housing demand further goes up.

Figure 2.

Impact of increasing housing demand on prices

(In case of constant supply)

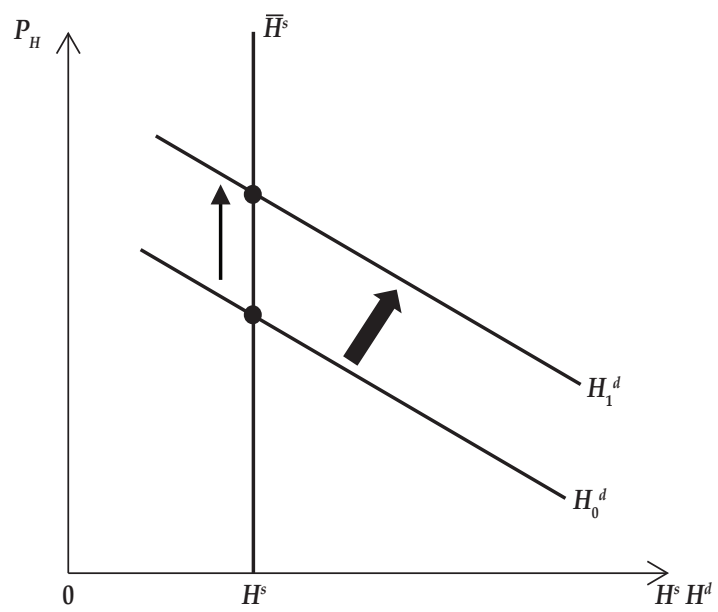

Source: Authors' compilation

$$
\begin{aligned}
& H_{t}^{d}=d_{0}-d_{1} P_{t}^{H}-d_{2} r_{t}+d_{3} P_{t}^{H^{e}}+d_{4} Y_{t}+d_{5} F D I_{t} \\
& H^{s}=\bar{H}^{s} \\
& r \downarrow \Rightarrow H^{d} \uparrow \Rightarrow P^{H} \uparrow \Rightarrow P^{H^{e}} \uparrow \Rightarrow H^{d} \uparrow
\end{aligned}
$$

When the investors in the real estate market understand that housing demand is increasing, they will start to invest and construct new houses. With a few years' lags, the housing supply will starts to increase, as the housing construction is a matter of time $\left(H_{t}^{d} \uparrow \Rightarrow H_{t+1}^{s} \uparrow\right)$. Then, the supply of houses shifts to the right, as in Figure 3, from $\bar{H}^{s}$ to $H_{t+1}^{s}$. This means that housing prices will suddenly start to fall a little bit, as is shown in Figure 3.

$$
\Delta H^{s}=\lambda\left(H_{t}^{d}-\bar{H}_{t}^{s}\right)
$$


Equation (4) shows that the housing supply adjustment is slow, and there is a time lag for the housing construction, which is $\lambda$. Suppose it takes three years to fill the demand gap, then, $\lambda$ is $1 / 3$. If the housing construction takes one year to be completed then $\lambda$ is equal to 1 .

$$
H_{t+1}^{S}-\bar{H}_{t}^{s}=\lambda\left(H_{t}^{d}-\bar{H}_{t}^{s}\right)
$$

Equation (5) shows that the housing supply gradually adjusts to the demand for housing.

$$
H_{t+1}^{S}=\lambda H_{t}^{d}+(1-\lambda) \bar{H}_{t}^{s}
$$

Equation (6) is obtained from Equation (5).

$$
H_{t+1}^{s}=\lambda\left(d_{0}-d_{1} P_{t}^{H}-d_{2} r_{t}+d_{3} P_{t}^{H^{e}}+d_{4} Y_{t}+d_{5} F D I_{t}\right)+(1-\lambda) \bar{H}_{t}^{s}
$$

Equation (7) shows the actual supply of housing in the following year. In Equation (7), if $\lambda$ is equal to 1 , then, the demand is fulfilled in the following year. In reality, $\lambda$ is usually smaller than 1 , meaning that housing construction usually takes more than 1 year.

Figure 3.

Impact of Increasing Housing Demand on Prices (Case of Increasing Supply)

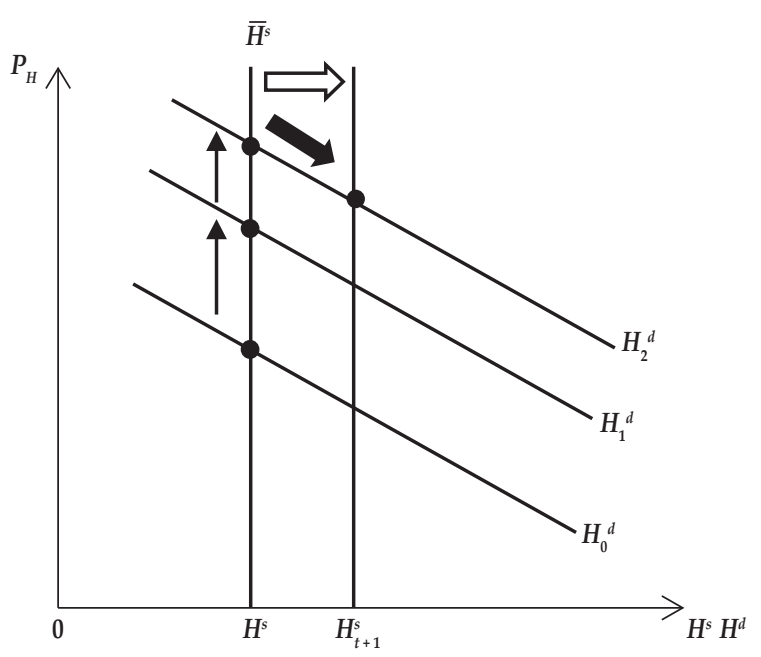

Source: Authors' compilation.

Equation (8) shows demand for housing in the following year. It shows that demand for housing in the following year is the function of the price of housing in the following year, interest rates of housing loans in the following year, expected 
price of housing in the next year, the income level of households in the next year and the foreign direct investment (FDI) of the next year.

$$
H_{t+1}^{d}=d_{0}-d_{1} P_{t+1}^{H}-d_{2} r_{t+1}+d_{3} P_{t+1}^{H^{e}}+d_{4} Y_{t+1}+d_{5} F D I_{t+1}
$$

When the supply of housing increases, the prices start to fall, then, the expected price of housing will also fall, which will have a negative impact on future demand for houses, as shown in Equation (9).

$$
P^{H} \downarrow \Rightarrow P^{H^{e}} \downarrow \Rightarrow H_{t+1}^{d} \downarrow
$$

This will shift housing demand down from $H_{2}{ }^{d}$ to $H_{1}{ }^{d}$, as shown in Figure 4 . Again, housing supply will keep on rising, causing the actual housing price to further fall because the expectation of housing price decreased. The continuous fall in housing prices due to the increase of newly built houses (new supply) and the simultaneous decrease in housing demand will burst the housing price bubble.

Figure 4.

Falling Housing Prices Due to New Supply and Decreased Demand

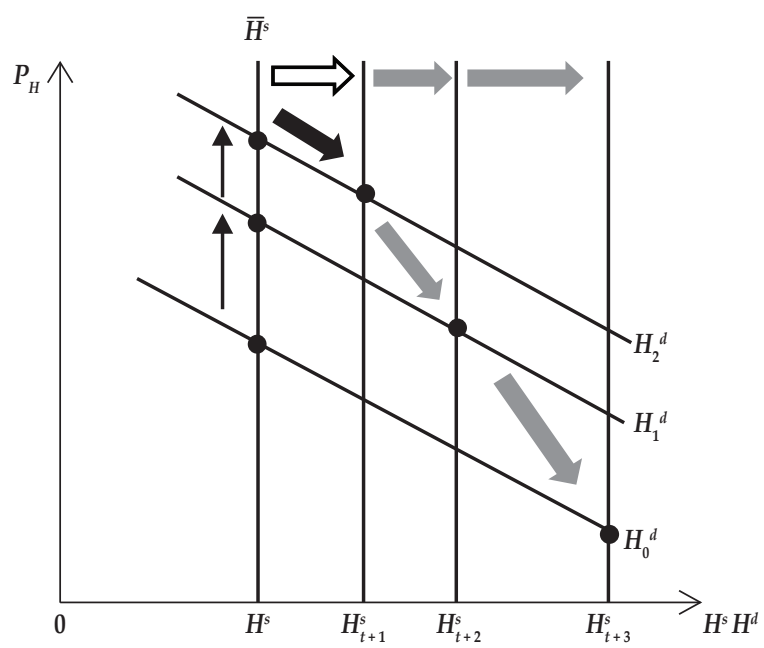

Source: Authors' compilation

$$
H_{t+2}^{s}-H_{t+1}^{s}=\lambda\left(H_{t+1}^{d}-H_{t+1}^{s}\right)
$$

Equation (10) shows the growth of housing supply in $t+2$, which is adjusted by $\lambda$.

$$
H_{t+2}^{d}=d_{0}-d_{1} P_{t+2}^{H}-d_{2} r_{t+2}+d_{3} P_{t+2}^{H^{e}}+d_{4} Y_{t+2}+d_{5} F D I_{t+2}
$$


Equation (11) shows the housing demand in $t+2$.

$$
\lambda H_{t}^{d}+(1-\lambda) \bar{H}_{t}^{s}=\underbrace{d_{0}-d_{1} P_{t+1}^{H}-d_{2} r_{t+1}+d_{3} P_{t+1}^{H^{e}}+d_{4} Y_{t+1}+d_{5} F D I_{t+1}}_{H_{t+1}^{d}}
$$

In Equation (12), the left-hand side comes from Equation (6), while the righthand side comes from Equation (8).

$$
P_{t+1}^{H}-\lambda P_{t}^{H}=\frac{1}{d_{1}}\left[\begin{array}{c}
(1-\lambda) d_{0}-d_{2}\left(r_{t+1}-\lambda r_{t}\right) \\
+d_{3}\left(P_{t+1}^{H^{e}}-\lambda P_{t}^{H^{e}}\right)+d_{4}\left(Y_{t+1}-\lambda Y_{t}\right) \\
-(1-\lambda) \bar{H}_{t}^{S}+d_{5}\left(F D I_{t+1}-\lambda F D I_{t}\right)
\end{array}\right]
$$

By rewriting Equation 12 for the price of housing, Equation 13 is obtained. It shows that the increase in the price of housing is a function of the adjusted constant demand, changes of the housing loan interest rate, changes in the expectation of housing price, changes in the income level of households, adjusted housing supply, and the changes of the flow of foreign capital.

$$
\frac{\partial P_{t+1}^{H}}{\partial P_{t+1}^{H^{e}}}=\frac{d_{3}}{d_{1}}>; \frac{\partial P_{t+1}^{H}}{\partial r_{t+1}}=-\frac{d_{2}}{d_{1}}<0 ; \quad \frac{\partial P_{t+1}^{H}}{\partial Y_{t+1}}=\frac{d_{4}}{d_{1}}>0 ; \frac{\partial P_{t+1}^{H}}{\partial \bar{H}_{t}^{s}}<0 ; \frac{\partial P_{t+1}^{H}}{\partial F D I_{t+1}}=\frac{d_{5}}{d_{1}}>0
$$

Equation (14) shows five inequalities that arise from the differences in housing price in Equation (14) with respect to different variables that we interpret from left to right. The first inequality in the left shows that the future expectation is that if the housing price goes up, then the price of housing goes up. The second inequality shows that, if the interest rate goes down, housing demand goes up, so, the housing price goes up. The third inequality shows that when the economy is in a boom state and the income level of the household goes up, the demand for housing increases and therefore the housing prices increase. The fourth inequality shows that when housing supply starts to increase, housing prices go down. The last inequality, or the rightmost one, shows that if the flow of foreign capital goes up, the demand for assets, including housing prices, increases due to increased demand by foreigners due to housing price increases.

Our theoretical model of demand and supply in the housing market sheds some light on some of the determinants of housing prices. It is clear that the demand-side determinants include variables, such as the level of income, preferences towards housing, housing prices, the interest rate on housing loans and inflow of foreign capital. Our theoretical model thus described the mechanisms through which a change in these variables affects housing prices.

\section{EMPIRICAL ANALYSIS}

This section presents our empirical analysis to establish the determinants of the current housing price bubble in Hong Kong. Our empirical analysis is based on monthly time series data from January 1999 to January 2018, for a total of 228 observations. 


\section{A. Data and Variables}

First, we use the housing price index of Hong Kong as a proxy for the evolution of housing prices in the special administrative region. Then, and in accordance with the theoretical model that we developed in the previous section, we include the demand and supply-side determinants of housing prices. To model the changes in the supply side, we use the number of newly completed housing units in Hong Kong, denoted H in logarithmic form. While studies such as Craig and Hua (2011), Glindro et al. (2008), and Leung et al. (2008) used construction costs or land supply index to approximate the supply in the housing markets, we decided to directly use the change in the number of newly constructed housing units provided by the Government of Hong Kong. From the demand side, we include the PRC and Hong Kong's Consumer Price Index (CPI) and nominal GDP in logarithmic form (i.e. $C C N, C H K, Y H K$ and $Y C N$, respectively), since we want to analyze how internal and external factors affect housing prices in Hong Kong. The use of these variables is in line with Glindro et al. (2008). We retrieve the quarterly data on the GDP variables from the Government of Hong Kong and the International Monetary Fund (IMF)'s International Financial Statistics (IFS) database. We retrieve the monthly data on the CPI variables from the OECD and the Government of Hong Kong's databases. Table 1 has a description of all variables.

Table 1.

Description of Variables

\begin{tabular}{|c|c|c|c|}
\hline Variable and Definition & Frequency & Symbol & Source \\
\hline $\begin{array}{l}\text { Private Domestic Housing Price } \\
\text { Indices (Territory-wide) (Referred to } \\
\text { as "housing price index") }\end{array}$ & Monthly & $i$ & $\begin{array}{l}\text { Government of Hong Kong, } \\
\text { China (2019) }\end{array}$ \\
\hline $\begin{array}{l}\text { M3 of Hong Kong, China } \\
\text { (in logarithm form) }\end{array}$ & Monthly & M3hk & $\begin{array}{l}\text { Hong Kong Monetary Authority } \\
\qquad(2019 a)\end{array}$ \\
\hline $\begin{array}{l}\text { M3 of PRC } \\
\text { (in logarithm form) }\end{array}$ & Quarterly & $M 3 c n$ & $\begin{array}{l}\text { Organization for Economic } \\
\text { Co-operation and Development } \\
\text { (2019a) }\end{array}$ \\
\hline $\begin{array}{l}\text { Housing lending interest rate in Hong } \\
\text { Kong, China }\end{array}$ & Monthly & Rhk & HSBC (2019) \\
\hline Housing lending interest rate in PRC & Quarterly & Ren & $\begin{array}{l}\text { International Monetary Fund, } \\
2019\end{array}$ \\
\hline $\begin{array}{l}\text { Percentage of newly approved } \\
\text { housing mortgages in total newly } \\
\text { issued loans to the private sector in } \\
\text { Hong Kong, China }\end{array}$ & Monthly & $M$ & $\begin{array}{l}\text { Hong Kong Monetary Authority } \\
\text { (2019) }\end{array}$ \\
\hline $\begin{array}{l}\text { Consumer Price Index (CPI) of Hong } \\
\text { Kong, China }\end{array}$ & Monthly & Chk & $\begin{array}{c}\text { Census and Statistics Department, } \\
\text { Hong Kong, China (2019a) }\end{array}$ \\
\hline Consumer Price Index (CPI) of PRC & Monthly & $C c n$ & $\begin{array}{c}\text { Organization for Economic } \\
\text { Co-operation and Development } \\
(2019 b)\end{array}$ \\
\hline $\begin{array}{l}\text { Gross Domestic Product of Hong } \\
\text { Kong, China }\end{array}$ & Quarterly & Yhk & $\begin{array}{c}\text { Census and Statistics Department, } \\
\text { Hong Kong, China (2019b) }\end{array}$ \\
\hline
\end{tabular}


Table 1.

Description of Variables (Continued)

\begin{tabular}{lccc}
\hline Variable and Definition & Frequency & Symbol & Source \\
\hline Gross Domestic Product of PRC & Quarterly & $Y_{c n}$ & $\begin{array}{c}\text { International Monetary Fund } \\
(2019)\end{array}$ \\
$\begin{array}{l}\text { Total newly completed housing units in } \\
\text { Hong Kong, China }\end{array}$ & Monthly & H & $\begin{array}{c}\text { Census and Statistics Department, } \\
\text { Hong Kong, China (2019c) }\end{array}$ \\
\hline
\end{tabular}

Source: Authors' compilation.

Besides, it is crucial to find a variable that reflects the preferences toward housing, and a variable that can also reflect the existence of housing bubbles. To this end, we adopt the measurement of mortgage-to-total loans as an indicator of bubbles in the housing market. Yoshino, Nakamura and Sakai (2014) illustrated that, in the 1980s-1990s, when loose monetary policy and excess liquidity produced the housing bubble in Japan, loans issued by banks leaned toward the real estate and construction sectors. After the burst of the asset price, especially the housing price bubble in Japan in 1990, for more than two decades, the Japanese economy went into a long-lasting recession (Yoshino \& Taghizadeh-Hesary 2016; Yoshino \& Taghizadeh-Hesary, 2017). The data for this particular variable was retrieved from the Hong Kong Monetary Authority.

In addition to the demand and supply variables, we also include policy variables that can affect housing demand. In particular, we decided to include money supply, inflation and interest rates. As we demonstrated throughout the literature review, these variables can have a crucial effect on housing demand. Therefore, we use the money supply $(M 3 H K)$ in logarithmic form and the lending interest rate $(R H K)$ of Hong Kong, which we retrieved from the Hong Kong Monetary Authority and HSBC, respectively. We chose to use M3 to reflect money supply, as it is a broad measure that includes both short- and long-term deposits as well as narrow money. Because we are interested in examining external factors affecting the housing prices in Hong Kong, we also include the same variables for the PRC. The variables for the PRC, denoted by M3CN and $R C N$, are retrieved from the OECD and the IMF's IFS databases, respectively. The arguments for M3CN are two-fold. As Su et al. (2019) showed, there is a causal link between money supply and housing prices in the PRC. Besides, our literature review proved the importance of external capital inflow as a determinant of housing prices. However, given the status of Hong Kong, we cannot simply analyze the FDIs in the special administrative region, because they might not include capital inflow from the PRC. Therefore, we use $M 3 C N$ as an approximation for capital inflows from the mainland to the housing markets of Hong Kong.

Finally, since data on some of the variables are only available at a quarterly frequency, we converted them to monthly frequency using cubic splineinterpolation (Chen and Tien, 1997) to have adequate observations for our empirical analysis. A spline is a tool for drawing a smooth curve in graphical science; mathematically, a piecewise-connected curve from which data are connected by mathematical functions is referred to as a spline curve. Spline curve fitting is useful especially for data with a sharp variation (Chen and Tien, 1997). 


\section{B. Preliminary Tests and First Diagnostics}

This section discusses the preliminary tests and diagnostics that we conducted to establish the suitability of the data for our empirical analysis.

First, we evaluate the series for stationarity to avoid spurious results in the analysis coming from the data series with a unit root. To check the stationarity of each variable, we employ the Augmented Dickey-Fuller (ADF), Zivot-Andrews (ZA), and Phillips-Perron (PP) tests. These results are shown in Appendix A, and show consistency across all three tests. All variables, except for $\operatorname{lnh}$, are stationary in their first differences. It should be noted, however, that we seasonally adjusted four variables (CCN, CHK, YCN, and YHK).

Since the variables are integrated of the same order, we apply the Johansen cointegration test and report the results in Appendix B. The test results indicate the presence of a long-run relationship among variables, which is often the case among macroeconomic variables. In particular, studies related to the Hong Kong market bubble using similar variables also reported cointegration in their data (Craig \& Hua, 2011; Glindro et al., 2008; Hui \& Wang, 2014).

We also conduct several diagnostics on serial correlation, heteroskedasticity and model misspecification and report these results in Appendix C. All test results show the presence of serial correlation and heteroskedasticity. Also, the RamseyRESET test results indicate that some variables are missing from the model's specification.

Finally, we check for the stability of our coefficients, and, in particular, we check whether our data has one or several structural breaks. Since the period of study covers the 2008 global financial crisis, it is possible that our coefficients are not stable throughout the whole sample. To this end, we conduct the CUSUM test. This test is a standard econometric technique, which constructs the cumulative sums of recursive residuals over time (Wenger and Leschinski, 2019). Under the null hypothesis, residuals are independent and identically distributed around 0 , with constant means and variances. The test checks for drift from the means and changes in variances over time.

Scholars have questioned the applicability of structural break tests, such as the Chow test, with cointegrated variables, and proposed the CUSUM test using residuals from cointegrated regressions instead (Kang \& Inder, 1996; Neto, 2014; Xiao \& Phillips, 2002). Similarly, Jiang \& Kurozumi (2020) recommended the CUSUM test using OLS residuals for models with a trend, which is our case. Following these studies, we decided to employ this test to check for the presence of a structural break in the data. Table 2 presents these test results.

Table 2.

\section{CUSUM Test for Coefficients Consistency}

Note: The null hypothesis is that the data presents no structural break. " $* *$ denotes significance at $10 \%$.

\begin{tabular}{lcccc}
\hline Description & Test Statistic & $\begin{array}{c}\mathbf{1 \%} \text { Critical } \\
\text { Value }\end{array}$ & $\begin{array}{c}\mathbf{5 \%} \text { Critical } \\
\text { Value }\end{array}$ & $\begin{array}{c}\mathbf{1 0 \%} \text { Critical } \\
\text { Value }\end{array}$ \\
\hline $\begin{array}{l}\text { Recursive } \\
\begin{array}{l}\text { Cumulative Sum of } \\
\text { Residuals }\end{array}\end{array}$ & $0.9143^{*}$ & 1.1430 & 0.9479 & 0.850 \\
\hline
\end{tabular}

Source: Authors' compilation using Stata 16. 
The results suggest that we failed to reject the null hypothesis with $95 \%$ confidence. This finding is in line with Lee (2017), who studied the nexus between residential property prices and stock prices in Hong Kong. Using the Chow breakpoint test, Lee (2017) established the presence of two break points in the second quarter of 1987 and the first quarter of 1998. From 1998 to 2015, the Lee (2017) did not find any structural breakpoint. Our finding is also confirmed by the unit root breakpoint test (ZA) that we conducted and reported in Appendix A.

\section{Empirical Model}

This section presents our empirical model. The estimated equation is in the loglinear form, with the housing price index of Hong Kong $(I)$ used as the dependent variable.

$$
\begin{aligned}
& I_{t}=\beta_{0}+\beta_{1} \log (M 3 c n)_{t}+\beta_{2} \log (M 3 h k)_{t}+\beta_{3}(R c n)_{t}+\beta_{4}(R h k)_{t}+\beta_{5}(M)_{t}+ \\
& \beta_{6}(C c n)_{t}+\beta_{7}(C h k)_{t}+\beta_{8} \log (Y c n)_{t}+\beta_{9} \log (Y h k)_{t}+\beta_{10} \log (H)_{t}+\varepsilon_{t}
\end{aligned}
$$

Given the presence of a cointegrating relationship among the variables, we can rewrite Equation (15) as:

$$
\begin{aligned}
& I_{t}=x^{\prime}{ }_{t} \beta+d^{\prime}{ }_{1} \gamma_{1}+u_{1 t} \\
& x_{t}=\Gamma_{1} d_{1 t}+\epsilon_{t} \\
& \Delta \epsilon_{t}=u_{2 t}
\end{aligned}
$$

where $d_{1 \mathrm{t}}$ is deterministic trend regressors, meaning the independent variables that are given by Equation (15). Assuming that the cointegrating equation errors $u_{1 t}$ and regressor innovations $u_{2 t}$ are stationary with zero means, the contemporaneous covariance matrix $\Sigma$, one-sided long-run covariance matrix $\Lambda$ and non-singular long-run covariance matrix $\Omega$ are given as follows:

$$
\begin{aligned}
\Sigma & =\left[\begin{array}{ll}
\sigma_{11} & \sigma_{12} \\
\sigma_{21} & \Sigma_{22}
\end{array}\right] \\
\Lambda & =\left[\begin{array}{ll}
\lambda_{11} & \lambda_{12} \\
\lambda_{21} & \Lambda_{22}
\end{array}\right] \\
\Omega & =\left[\begin{array}{ll}
\omega_{11} & \omega_{12} \\
\omega_{21} & \Omega_{22}
\end{array}\right]
\end{aligned}
$$

Because there exists a long-run correlation between the cointegrating equation errors $u_{1 t}$ and regressor innovations $u_{2 t^{\prime}}$ the regular OLS estimator fails to provide non-biased results and generally involves nuisance parameters. To solve this issue, Phillips and Hansen (1990) and Park (1992) proposed modified versions of the OLS estimators, the fully modified OLS (FMOLS) and cardinal cointegrating regression (CCR), respectively. Using heteroskedasticity and autocorrelation consistent (HAC) standard errors, these methods of estimations allow for asymptotically unbiased and efficient estimates. 
The FMOLS proposed by Phillips and Hansen (1990) consists of transforming the independent variables by using estimates from the long-run covariance matrix:

$$
I_{t}^{+}=I_{t}-\widehat{\omega}_{12} \widehat{\Omega}_{22}^{-1} \widehat{u}_{2 t}
$$

Then, the FMOLS estimators and covariance are given by:

$$
\begin{aligned}
& \hat{\theta}=\left[\begin{array}{c}
\hat{\beta} \\
\hat{\gamma}_{1}
\end{array}\right]=\left[\sum_{t=1}^{T} z_{t} z^{\prime}{ }_{t}\right], z_{t}=\left(x^{\prime}{ }_{t} d^{\prime}{ }_{1 t}\right)^{\prime} \\
& \operatorname{Var}(\hat{\theta})=\widehat{\omega}_{12}\left[\sum_{t=1}^{T} z_{t} z^{\prime}{ }_{t}\right]
\end{aligned}
$$

On the other hand, the CCR estimates transform both regressors and independent variables as follow:

$$
\begin{aligned}
& I_{t}^{+}=I_{t}-\left\{\widehat{\Sigma}^{-1}\left(\begin{array}{l}
\widehat{\Lambda}_{12} \\
\widehat{\Lambda}_{22}
\end{array}\right) \tilde{\beta}+\left(\begin{array}{cc}
0 & \cdot \\
\hat{\Omega}_{22}^{-1} & \widehat{\omega}_{21}
\end{array}\right)\right\}^{\prime}\left(\widehat{u}_{1 t}, \widehat{u}_{2 t}^{\prime}\right)^{\prime} \\
& x_{t}^{+}=x_{t}-\left(\hat{\Sigma}^{-1} \widehat{\Lambda}_{2}\right)^{\prime}\left(\hat{u}_{1 t}, \widehat{u}_{2 t}^{\prime}\right)^{\prime}
\end{aligned}
$$

where $\tilde{\beta}$ is the OLS estimator.

Park (1992)'s model is a generalization of Phillips and Hansen (1990)'s FMOLS, as it incorporates deterministic time trends. Since our variables (including independent ones) likely do present deterministic trends, we decided to use both models, for robustness.

Finally, because of the suspicion of endogeneity due to omitted variables, we also use Saikkonen (1992) and Stock and Watson (1993)'s dynamic OLS (DOLS), which includes the lagged version of $\Delta x_{t}$ to reduce the long-run correlation and reduce the bias linked with endogeneity as follows:

$$
I_{t}=x_{t}^{\prime} \beta+d_{1}^{\prime} \gamma_{1}+\sum_{j=-q}^{r} \Delta x_{t+j}+v_{1 t}
$$

This model is developed for variables integrated of order 1 , which is the case for our study.

\section{Results}

This section presents and discusses our empirical results based on the cointegration specifications in Section C. Table 3 reports these results. First, it appears clear that the results from the FMOLS and CCR estimators, which correct for serial correlation, heteroskedasticity and deterministic trend, are quite similar. Overall, DOLS estimator is the best estimator regarding the goodness of fit, a fact that could be explained by a better correction for endogeneity. 
Table 3.

\section{Empirical Results}

Note: Results are rounded to two decimals. The dependent variable is i. Source: Authors' compilation using Stata 16.

\begin{tabular}{|c|c|c|c|}
\hline Estimation Method & FMOLS & CCR & DOLS \\
\hline $\ln m 3 c n$ & $\begin{array}{c}85.29^{* * *} \\
(18.20)\end{array}$ & $\begin{array}{l}84.77^{* * * *} \\
(21.50)\end{array}$ & $\begin{array}{c}19.72 \\
(21.55)\end{array}$ \\
\hline $\operatorname{lnm} 3 h k$ & $\begin{array}{l}-14.93 \\
(16.13)\end{array}$ & $\begin{array}{l}-16.17 \\
(19.79)\end{array}$ & $\begin{array}{l}47.80^{* *} \\
(20.97)\end{array}$ \\
\hline $\mathrm{rCn}$ & $\begin{array}{l}-0.39 \\
(0.99)\end{array}$ & $\begin{array}{c}-0.380182 \\
(1.062026)\end{array}$ & $\begin{array}{l}0.9116168 \\
(1.008233)\end{array}$ \\
\hline$r h k$ & $\begin{array}{l}-0.84 \\
(0.88)\end{array}$ & $\begin{array}{l}-0.83 \\
(0.94)\end{array}$ & $\begin{array}{l}-0.51 \\
(0.92)\end{array}$ \\
\hline $\mathrm{cCn}$ & $\begin{array}{c}2.72^{* * *} \\
(0.80)\end{array}$ & $\begin{array}{c}2.68^{* * *} \\
(0.85)\end{array}$ & $\begin{array}{c}2.98^{* * *} \\
(0.87)\end{array}$ \\
\hline cchk & $\begin{array}{c}5.65^{* * *} \\
(0.48)\end{array}$ & $\begin{array}{c}5.68^{* * *} \\
(0.52)\end{array}$ & $\begin{array}{c}5.32^{* * *} \\
(0.54)\end{array}$ \\
\hline $\ln y c n$ & $\begin{array}{c}-177.31^{* * *} \\
(27.91)\end{array}$ & $\begin{array}{c}-175.64^{* * *} \\
(31.09)\end{array}$ & $\begin{array}{c}-97.90^{* * *} \\
(32.15)\end{array}$ \\
\hline $\ln y h k$ & $\begin{array}{c}275.00 * * * \\
(31.37)\end{array}$ & $\begin{array}{c}274.83^{* * *} \\
(35.56)\end{array}$ & $\begin{array}{c}152.99^{* * *} \\
(38.08)\end{array}$ \\
\hline$m$ & $\begin{array}{c}37.52 \\
(50.89)\end{array}$ & $\begin{array}{l}37.69 \\
(59.10)\end{array}$ & $\begin{array}{c}181.97^{* * *} \\
(59.98)\end{array}$ \\
\hline $\operatorname{lnh}$ & $\begin{array}{l}-0.91 \\
(0.67)\end{array}$ & $\begin{array}{c}-0.92 \\
(0.75)\end{array}$ & $\begin{array}{l}-1.28 \\
(1.01)\end{array}$ \\
\hline constant & $\begin{array}{c}-4897.28^{* * *} \\
(553.76) \\
\end{array}$ & $\begin{array}{c}-4872.01^{* * *} \\
(620.26) \\
\end{array}$ & $\begin{array}{c}-2999.12^{* * *} \\
(638.80) \\
\end{array}$ \\
\hline $\mathrm{R}^{2}$ & 0.96 & 0.96 & 0.99 \\
\hline Adjusted $\mathrm{R}^{2}$ & 0.96 & 0.96 & 0.99 \\
\hline Standard Error & 17.74 & 17.73 & 9.53 \\
\hline Long Run Standard Error & 6.32 & 6.32 & 5.24 \\
\hline
\end{tabular}

Second, we see that the supply-side determinant, namely the number of newly constructed housing units $(H)$ is not statistically significant, regardless of the estimator. This finding is in accordance with Glindro et al. (2008) but contradicts the finding of Craig \& Hua (2011); this contradiction merely comes from the difference in variables used to represent the supply side. While increasing the land supply is an efficient way of driving residential prices down (Craig \& Hua, 2011), our results show that housing supply is not affected and does not affect price changes. This comes from the fact that the production of housing units in both public and private sectors has been kept at low levels since 2003. This supply-demand disequilibrium is a result of government policies. As housing prices began falling prior to 2003, government finance and political stability were compromised (HKMA, 2000). Subsequently, Hong Kong entered an era of low provision of new housing units. Newly completed housing units have, since, then, never been above 6000 HKD per month, with some recorded months being as low as less than a hundred. Following the Asian Crisis of 1999 and SARS of 2003, the government paused the construction of home-ownership schemes, a type of subsidized, government-run public housing for sale, and opted for a Land Application List System, in which the 
government no longer put available lands for sale regularly; instead, developers now choose land from a list of land for sale offered by the government and provide a quote, followed by an open auction (Wong, 2008). Using land supply is, hence, not a correct reflection of the state of the market in Hong Kong.

On the demand side, the bubble indicator and reflection of preferences towards housing $(M)$ are shown to be only statistically significant when using the DOLS estimator. This should not come as a surprise because the DOLS estimator addresses the omitted variable bias problem, and, likely, $M$ cannot fully capture preferences towards housing. Nevertheless, this variable shows a positive and significant sign, indicating that higher preferences towards housing, as reflected by the share of mortgage loans out of all issued loans, leads to higher housing prices. Hence, in the case of the housing market in Hong Kong, the demand side affects housing prices far more than the supply side.

In turn, it is unsurprising to see that the policy variables that affect the demand side, such as inflation, interest rate, and money supply, are also significant, to an extent. As shown by all estimators, the coefficient of inflation in the PRC and Hong Kong ( $\mathrm{CCN}$ and $\mathrm{CHK}$ ) is positive, showing the close links between macroeconomic factors in Hong Kong and the PRC. The significance of the inflation rate is in line with Tsai and Peng (2011). Interest rate is shown not to impact housing prices, a fact that could reflect that housing has become unaffordable for the average citizen, regardless of the changes in the lending interest rate. This result is in line with Leung et al. (2008), who showed that the interest rate played a small role in the surge in housing prices in the Hong Kong property market. The significance of money supply (M3CN and $M 3 H K$ ) can be explained differently. The money supply in Hong Kong can increase the demand for credit, and eventually increase the demand for assets and housing; this is not the case for the money supply from the PRC. The significance of M3HK is in line with Su et al. (2019). On the other hand, we used $M 3 C N$ as an instrument to approximate the capital inflow from the PRC to Hong Kong. The results highlight that higher investments from the PRC directly lead to higher housing prices.

Finally, the level of income in Hong Kong and the PRC are both statistically significant, but with opposite signs. YHK shows a positive sign, implying that a higher level income growth in the special administrative region directly translates into higher prices. This result is predicted by our theoretical model and is in line with Glindro et al. (2008). On the other hand, a negative sign on the variable YCN means that, when the growth in the Chinese economy slows down, it directly translates into higher prices in the Hong Kong housing markets. This negative and statistically significant sign implies that part of the surge in housing prices in Hong Kong is driven by PRC homeowners, whose demand for houses in the special administrative territory merely comes from a desire to keep their assets' value in times of recession in the PRC. This finding is particularly relevant in the present extremely uncertain times induced by the COVID-19 pandemic. ${ }^{3}$ Together

3 Several recent studies showed that the COVID-19 pandemic has made global economies extremely uncertain (see Devpura and Narayan, 2020; Iyke, 2020; Narayan, 2020; Sharma, 2020; Yoshino, Taghizadeh-Hesary and Otsuka, 2020 among others). This finding implies that the PRC's homeowners will be seeking to preserve their wealth in the Hong Kong housing market, given the rise in uncertainty around the world, including the PRC. 
with $M 3 C N$, this shows that the surge in housing prices in Hong Kong can be partially attributed to the increased demand and investments from the PRC.

\section{CONCLUSION AND POLICY IMPLICATIONS}

Following the steady increase in prices in the housing market in Hong Kong, this paper analyzed the determinants behind this rise. Based on simple aggregate demand and supply model and a monthly data from January 1999 to January 2018 the paper explored the role of external factors in the rise of housing prices in Hong Kong, particularly, focusing on the role of macroeconomic factors from the PRC.

The literature review showed that we can classify the determinants of housing prices into different categories: (i) demand-and supply-side factors, such as income, preferences towards housing or land supply or construction costs, (ii) factors that affect demand and supply, such as monetary and fiscal policy instruments, and (iii) external determinants, such as capital inflow and investment. The theoretical model we developed analyses the mechanisms through which the demand for and the supply of housing leads to price discovery in the housing market. In particular, the model clarified the relationship and mechanisms between parameters that constitute the housing demand (income, interest rate, capital inflow, housing prices) and housing prices in the next period.

Using cointegrating regression estimators, namely FMOLS, DOLS and CCR, the main findings of this study emphasized the importance of the demand side, while we showed that changes in the housing supply in Hong Kong did not significantly affect the overall housing price index. Hence, it was unsurprising that variables affecting the demand side were also shown to be significantly affecting the movements of housing prices in Hong Kong. The level of income, inflation and money supply in Hong Kong tended to positively influence the housing price index of the special administrative region. The main contribution of this study was the analysis of the role of external factors, specifically the PRC's macroeconomic factors, in the changes in housing prices in Hong Kong. The study showed that not only are the PRC's money supply, inflation and income growth significantly influencing housing prices in the special administrative region, but their relative influence is also as large as their internal counterparts. Higher inflation and capital inflow from the PRC significantly increase housing prices in the special administrative region. On the other hand, income growth of the PRC is negatively related to housing price in the the special administrative region. This implies that the demand for housing in Hong Kong from the mainland is driven by the need to preserve asset value in a city, where real estate represents a sound investment, in times of recession in the PRC.

These findings contain some important implications for policymakers. They show that one of the main reasons for price appreciation in the Hong Kong housing market is the increased demand from the PRC. This means that residents of the special administrative region are losing affordability in their city because of external speculations. Therefore, the government of Hong Kong needs to focus its efforts on controlling money flows between the PRC and the special administrative region, in addition to sanctioning owners of empty houses to prevent the decrease in housing supply due to speculative purchasing of apartments in the city. 
Acknowledgement: Farhad Taghizadeh-Hesary acknowledges the financial supports of the JSPS Kakenhi (2019-2020) Grant-in-Aid for Young Scientists No. 19K13742, and Grant-in-Aid for Excellent Young Researcher of the Ministry of Education of Japan (MEXT). Authors are grateful to Prof Paresh Narayan and the anonymous reviewers of the BMEB for providing precious comments on the first version of this paper that helped a lot to revise and prepare this version.

\section{REFERENCES}

Ahuja, A., \& Porter, N. (2010). Are House Prices Rising Too Fast in Hong Kong SAR? (WP/10/273). International Monetary Fund. Retrieved from International Monetary Fund: https://www.imf.org/en/Publications/WP/Issues/2016/12/31/ Are-House-Prices-Rising-too-Fast-in-Hong Kong-SAR-24403 APEC (2020). StatsAPEC: Bilateral Linkages Database. Asia-Pacific Economic Cooperation.

Bian, T., \& Gete, P. (2015). What drives housing dynamics in China? A sign restrictions VAR approach. Journal of Macroeconomics, 46, 94-112. http://search. proquest.com/docview/1752000298/

Census \& Statistics Department, Hong Kong, China. (2019a). Prices Overview. Census and Statistics Department. Retrieved from https://www.censtatd.gov. hk/hkstat/sub/so60.jsp

Census \& Statistics Department, Hong Kong, China. (2019b). National Income. Census and Statistics Department. Retrieved from https://www.censtatd.gov. hk/hkstat/sub/so250.jsp

Census \& Statistics Department, Hong Kong, China. (2019c). Housing and Property. Census and Statistics Department Retrieved from https://www.censtatd.gov. hk/hkstat/sub/sp100.jsp?productCode=B1010003

Census \& Statistics Department, Hong Kong, China Census and Statistics Department, Hong Kong, China. (20120). Housing and Property. Census and Statistics Department. Retrieved from https://www.censtatd.gov.hk/hkstat/ sub/sp260.jsp? subjectID=260\&tableID=048\&ID=0\&productType $=8$

Chen, C., \& Tien, T. (1997). A New Forecasting Method of Discrete Dynamic System. Applied Mathematics and Computation, 86, 61-84. https://doi.org/10.1016/S00963003(96)00173-7

Chen K., H. Long, C. Qin (2020).The Impacts of Capital Deepening on Urban Housing Prices: Empirical Evidence from 285 Prefecture-Level or above Cities in China. Habitat International. 99, 102173. https://doi.org/10.1016/j. habitatint.2020.102173.

Craig, R. S. \& Hua, C. (2011). Determinants of Property Prices in Hong Kong SAR: Implications for Policy. (WP/11/277). International Monetary Fund. Retrieved from International Monetary Fund: https://www.imf.org/en/Publications/ WP/Issues/2016/12/31/Determinants-of-Property-Prices-in-Hong Kong-SARImplications-for-Policy-25389

Devpura, N., \& Narayan, P.K., (2020) Hourly Oil Price Volatility: The Role of COVID-19. Energy Research Letters, 1, 13683. https://doi.org/10.46557/001c.13683

Glindro, E., Szeto, J., \& Zhu, H. (2008). Determinants of House Prices in Nine Asia-Pacific Economies. IDEAS Working Paper Series from RePEc. http://search. proquest.com/docview/1697753813/ 
Government of Hong Kong, China. (2019). Property Market Statistics. Rating and Valuation Department. Retrieved from https://www.rvd.gov.hk/en/property_ market_statistics/index.html

Guest, R., \& Rohde, N. (2017). The Contribution of Foreign Real Estate Investment to Housing Price Growth in Australian Capital Cities. Abacus, 53, 304-318. https://doi.org/10.1111/abac.12110

Ho, L., \& Wong, G. (2008). Nexus Between Housing and the Macroeconomy: the Hong-Kong Case. Pacific Economic Review, 13, 223-239. https://doi.org/10.1111/ j.1468-0106.2008.00398.x

Hong Kong Monetary Authority. (2019). Monthly Statistical Bulletin. Hong Kong Monetary Authority. Retrieved from https://apidocs.hkma.gov.hk/ documentation/market-data-and-statistics/monthly-statistical-bulletin/

HSBC. (2019). Insights - Analysis and Market Data. The Hongkong and Shanghai Banking Corporation. Retrieved from https://www.hsbc.com.hk/wealth/ insights/

Hui, E., \& Wang, Z. (2014). Price Anomalies and Effectiveness of Macro Control Policies: Evidence from Chinese Housing Markets. Land Use Policy, 39, 96-109. https://doi.org/10.1016/j.landusepol.2014.04.003

International Monetary Fund. (2019). International Financial Statistics. International Monetary Fund. Retrieved from https://data.imf.org/?sk=4c514d48-b6ba-49ed8ab9-52b0c1a0179b

Iyke, B. N. (2018), Assessing the Effects of Housing Market Shocks on Output: the Case of South Africa. Studies in Economics and Finance, 35, 287-306. https://doi. org/10.1108/SEF-09-2016-0237

Iyke, B. N. (2020). Economic Policy Uncertainty in Times of COVID-19 Pandemic. Asian Economics Letters, 1. https://doi.org/10.46557/001c.17665

Jiang, P., \& Kurozumi, E. (2020). Monitoring Parameter Changes in Models with a Trend. Journal of Statistical Planning and Inference, 207, 288-319. https://doi. org/10.1016/j.jspi.2020.01.004

Justiniano, A., Giorgio E. P., \& Tambalotti, A.. (2015). Credit Supply and Housing Boom. The Federal Reserve Bank of New York. https://www.newyorkfed.org/ medialibrary/media/research/staff_reports/sr709.pdf

Kalra, S., Mihaljek, D., \& Duenwald, C. (2000). Property Prices and Speculative Bubbles: Evidence from Hong Kong SAR. . (WP/00/2). International Monetary Fund. Retrieved from International Monetary Fund: https://www.imf.org/en/ Publications/WP/Issues/2016/12/30/Property-Prices-and-Speculative-BubblesEvidence-From-Hong Kong-SAR-3383

Kang Hao, \& Inder, B. (1996). Diagnostic Test for Structural Change in Cointegrated Regression Models. Economics Letters, 50, 179-187. https://doi.org/10.1016/01651765(95)00750-4

Lee, K. (2017). Residential Property Price-Stock Price Nexus in Hong Kong: New Evidence from ARDL Bounds Test. International Journal of Housing Markets and Analysis, 10, 204-220. https://doi.org/10.1108/IJHMA-03-2016-0020

Leung, F., Chow, K., \& Han, G. (2008). Long-term and Short-term Determinants of Property Prices in Hong Kong. IDEAS Working Paper Series from RePEc. http:// search.proquest.com/docview/1698499233/ 
Narayan, P. K. (2020). Did Bubble Activity Intensify During COVID-19? Asian Economics Letters, 1. https://doi.org/10.46557/001c.17654

Neto, D. (2014). The FMLS-based CUSUM statistic for testing the null of smooth time-varying cointegration in the presence of a structural break. Economics Letters, 125, 208-211. https://doi.org/10.1016/j.econlet.2014.09.009

Organization for Economic Co-operation and Development. (2019a). M3 for China [MABMM301CNQ189S]. Federal Reserve Bank of St. Louis. Retrieved from FRED, Federal Reserve Bank of St. Louis; https://fred.stlouisfed.org/series/ MABMM301CNQ189S, March 1st, 2019.

Organization for Economic Co-operation and Development. (2019b). Consumer Price Index: All Items for China [CHNCPIALLMINMEI]. Federal Reserve Bank of St. Louis. Retrieved from FRED, Federal Reserve Bank of St. Louis; https://fred. stlouisfed.org/series/CHNCPIALLMINMEI, March 1st, 2019.

Park, J. (1992). Canonical Cointegrating Regressions. Econometrica, 60, 119-143. https://doi.org/10.2307/2951679

Phillips, P., \& Hansen, B. (1990). Statistical Inference in Instrumental Variable Regression with I(1) Processes. Review of Economic Studies, 57, 99-125. https:// doi.org/10.2307/2297545

Sa, F., \& Wieladek, T. (2010). Monetary policy, capital inflows and the housing boom. Bank of England. Quarterly Bulletin, 50, 350. http://search.proquest.com/ docview/851792415/

Saikkonen, P. (1992). Estimation and testing of cointegrated systems by an autoregressive approximation. Econometric Theory, 8, 1-27. http://search. proquest.com/docview/37749228/

Sharma, S. S. (2020). A Note on the Asian Market Volatility During the COVID-19 Pandemic. Asian Economics Letters, 1. https://doi.org/10.46557/001c.17661

Stock, J., \& Watson, M. (1993). A Simple Estimator of Cointegrating Vectors in Higher Order Integrated Systems. Econometrica (1986-1998), 61, 783-820. https://doi.org/10.2307/2951763

Su, C., Wang, X., Tao, R., \& Chang, H. (2019). Does Money Supply Drive Housing Prices in China? International Review of Economics and Finance, 60, 85-94. https:// doi.org/10.1016/j.iref.2018.12.013

Taghizadeh Hesary, F., \& Yoshino, N. (2014). Monetary policies and oil price determination: an empirical analysis. OPEC Energy Review, 38, 1-20. https:// doi.org/10.1111/opec.12021

Taghizadeh-Hesary, F., \& Yoshino, N. (2016). Monetary Policy, Oil Prices and the Real Macroeconomic Variables: An Empirical Survey on China, Japan and the United States. China: An International Journal, 14, 46-69 https://muse.jhu.edu/ article/640270

Tsai, I., \& Peng, C. (2011). Bubbles in the Taiwan Housing Market: The Determinants and Effects. Habitat International, 35, 379-390. https://doi.org/10.1016/j. habitatint.2010.11.010

Wenger, K., \& Leschinski, C. (2019). Fixed-bandwidth CUSUM Tests under long Memory. Econometrics and Statistics. https://doi.org/10.1016/j.ecosta.2019.08.001 
Wokker, C., \& Swieringa, J. (2016). Foreign Investment and Residential Property Price Growth. IDEAS Working Paper Series from RePEc. http://search.proquest. com/docview/1855448386/

Wong, G. (2008). HasSARSinfected the property market? Evidencefrom Hong Kong. Journal of Urban Economics, 63, 74-95. https://doi.org/10.1016/j.jue.2006.12.007.

Wu, T., Wong, K. and Cheng, M. (2017). Estimating the Drivers of Hong Kong's Housing Price Short-Run Dynamics. Hong Kong Monetary Authority. Retrieved from the Hong Kong Monetary Authority: https://www.hkma.gov.hk/media/ eng/publication-and-research/research/research-memorandums/2017/RM032017.pdf

Xiao, Z., \& Phillips, P. (2002). A CUSUM Test for Cointegration Using Regression Residuals. Journal of Econometrics, 108, 43-61. https://doi.org/10.1016/S03044076(01)00103-8

Yiu, M., \& Sahminan, S. (2015). Global Liquidity, Capital Inflows and House Prices in ASEAN Economies. SSRN Electronic Journal. https://doi.org/10.2139/ ssrn.2617193

Yiu, M., Yu, J., \& Jin, L. (2013). Detecting Bubbles in Hong Kong Residential Property Market. Journal of Asian Economics, 28. http://search.proquest.com/ docview/1444562891/

Yoshino, N., Nakamura, T., \& Sakai, Y. (2014). International Comparison of Bubbles and Bubble Indicators. AI \& SOCIETY, 29, 427-434. https://doi.org/10.1007/s00146-013-0469-8

Yoshino, N., \& Taghizadeh-Hesary, F. (2014). Monetary Policy and Oil Price Fluctuations Following the Subprime Mortgage Crisis. International Journal of Monetary Economics and Finance, 7, 157-174. https://doi.org/10.1504/ IJMEF.2014.066482

Yoshino, N., \& Taghizadeh-Hesary, F. (2016). Causes and Remedies of the Japan's Long lasting Recession: Lessons for China. China \& World Economy, 24, 23-47. https://doi.org/10.1111/cwe.12149

Yoshino, N., \& Taghizadeh-Hesary, F. (2017). Japan's Lost Decade: Lessons for Asian Economies. Edited by Naoyuki Yoshino, Farhad Taghizadeh-Hesary. (1st ed. 2017.). Springer Tokyo. https://doi.org/10.1007/978-981-10-5021-3

Yoshino, N., Taghizadeh-Hesary, F., \& Otsuka, M. (2020). Covid-19 and Optimal Portfolio Selection for Investment in Sustainable Development Goals. Finance Research Letters, 101695. https://doi.org/10.1016/j.frl.2020.101695 


\section{Appendix A. \\ Stationarity Analysis}

Note: Results are rounded to two decimals, and variables have been tested with the trend. "ADF" refers to the Augmented Dickey-Fuller Test; "ZA" refers to the Zivot Andrews Test. "PP" refers to the Phillips-Perron Test. Source: Authors' compilation using Stata 16.

\begin{tabular}{|c|c|c|c|c|}
\hline \multirow{2}{*}{ Variable } & & ADF & $\mathrm{ZA}$ & PP \\
\hline & & $t$-stat. & Minimum $t$-stat. & $t$-stat. \\
\hline \multirow[t]{2}{*}{$i$} & Levels & 0.160 & -2.040 & -0.444 \\
\hline & D1 & $-8.64^{* * *}$ & $-8.744^{* * *}$ & $-8.70^{* * *}$ \\
\hline \multirow[t]{2}{*}{$\ln m 3 c n$} & Levels & 1.76 & -1.520 & 1.49 \\
\hline & D1 & $-15.22^{* * *}$ & $-7.562^{* * *}$ & $-15.33^{* * *}$ \\
\hline \multirow[t]{2}{*}{$\operatorname{lnm} 3 h k$} & Levels & -2.03 & -4.236 & -1.99 \\
\hline & D1 & $-16.34^{* * *}$ & $-8.220^{* * *}$ & $-16.37^{* * *}$ \\
\hline \multirow[t]{2}{*}{$\mathrm{rcn}$} & Levels & -2.16 & -3.406 & -2.26 \\
\hline & D1 & $-14.80^{* * *}$ & $-15.030^{* * *}$ & $-14.80^{* * *}$ \\
\hline \multirow[t]{2}{*}{ rhk } & Levels & -0.87 & $-4.820^{* *}$ & -1.74 \\
\hline & D1 & $-7.55^{* * *}$ & $-5.102^{* *}$ & $-7.51^{* * *}$ \\
\hline \multirow[t]{2}{*}{$\mathrm{ccn}^{4}$} & Levels & -2.16 & -3.045 & -2.08 \\
\hline & D1 & $-15.88^{* * *}$ & $-6.320^{* * *}$ & $-16.11^{* * *}$ \\
\hline \multirow[t]{2}{*}{$\operatorname{ch} k^{1}$} & Levels & -0.27 & -2.333 & -0.27 \\
\hline & D1 & $-18.42^{* * *}$ & $-5.766^{* * *}$ & $-18.28^{* * *}$ \\
\hline \multirow[t]{2}{*}{$\operatorname{lnycn^{1}}$} & Levels & 2.35 & -0.226 & 0.99 \\
\hline & D1 & $-4.66^{* * *}$ & -3.762 & $-4.49^{* * *}$ \\
\hline \multirow[t]{2}{*}{$\operatorname{lyh} k^{1}$} & Levels & -1.45 & $-5.719^{* * *}$ & -2.00 \\
\hline & D1 & $-8.87^{* * *}$ & $-6.243^{* * *}$ & $-8.84^{* * *}$ \\
\hline \multirow[t]{2}{*}{$m$} & Levels & -2.67 & -3.520 & $-2.85^{* * *}$ \\
\hline & D1 & $-19.07^{* * *}$ & $-6.828^{* * *}$ & $-18.95^{* * *}$ \\
\hline \multirow[t]{2}{*}{$\operatorname{lnh}$} & Levels & $-5.41^{* * *}$ & $-7.734^{* * *}$ & $-5.84^{* * *}$ \\
\hline & D1 & $-11.09^{* * *}$ & $-11.662^{* * *}$ & $-10.44^{* * *}$ \\
\hline
\end{tabular}

4 Seasonally adjusted using eViews 10. 


\section{Appendix B. \\ Johansen Test for Cointegration}

Note: Results are rounded to two decimals. Test performed on $i, \ln m 3 c n, \ln m 3 h k, r c n, r h k, c c n, c h k, \ln y c n, \ln y h k, m$, and lnh. Source: Authors' compilation using Stata 16.

\begin{tabular}{lcccc}
\hline Maximum Rank & $\begin{array}{c}\text { Number of } \\
\text { Parameters }\end{array}$ & Eigen Value & Trace Statistic & $\begin{array}{c}\mathbf{5 \%} \text { Critical } \\
\text { Value }\end{array}$ \\
\hline 0 & 132 &. & 468.69 & 277.71 \\
1 & 153 & 0.43 & 343.09 & 233.13 \\
2 & 172 & 0.30 & 262.73 & 192.89 \\
3 & 189 & 0.25 & 198.62 & 156.00 \\
4 & 204 & 0.21 & 145.99 & 124.24 \\
5 & 217 & 0.18 & 102.23 & 94.15 \\
6 & 228 & 0.12 & 73.89 & 68.52 \\
7 & 237 & 0.11 & 47.73 & 47.21 \\
8 & 244 & 0.08 & 29.74 & 29.68 \\
9 & 249 & 0.06 & $14.95^{*}$ & 15.41 \\
10 & 252 & 0.05 & 3.88 & 3.76 \\
\hline
\end{tabular}

\section{Appendix C. \\ Diagnostics}

Note: Results are rounded to two decimals. Test performed on i lnm3cn lnm3hk ren rhk ccn chk lnycn lnyhk m lnh. Source: Authors' compilation using Stata 16.

\begin{tabular}{|c|c|c|c|c|}
\hline Description & Test & Null Hypothesis & Statistic & Probability \\
\hline \multirow{3}{*}{ Serial Correlation } & $\begin{array}{l}\text { Engle's Lagrange Multiplier } \\
\text { test for ARCH disturbance }\end{array}$ & No serial correlation & 155.07 & 0.00 \\
\hline & $\begin{array}{l}\text { Breusch-Godfrey for higher- } \\
\text { order serial correlation in } \\
\text { disturbance }\end{array}$ & No serial correlation & 184.64 & 0.00 \\
\hline & $\begin{array}{l}\text { Durbin alternative test } \\
\text { for higher-order serial } \\
\text { correlation in disturbance }\end{array}$ & No serial correlation & 1015.578 & 0.00 \\
\hline Heteroskedasticity & $\begin{array}{l}\text { Breusch-Pagan / Cook- } \\
\text { Weisberg test for } \\
\text { heteroskedasticity }\end{array}$ & Homokedasticity & 106.42 & 0.00 \\
\hline Endogeneity & $\begin{array}{l}\text { Ramsey RESET test for } \\
\text { omitted variables }\end{array}$ & No omitted variables & 9.01 & 0.00 \\
\hline
\end{tabular}

